\title{
Quality of health care for refugees - a systematic review
}

\author{
Karolin Hahn, Jost Steinhäuser, Denise Wilfling and Katja Goetz (B)
}

\begin{abstract}
Objective: The aim of this systematic review was to identify quality indicators (QI) developed for health care for refugees.

Methods: We conducted a systematic review of international QI databases such as the Agency for Health care Research and Quality in addition to a systematic search in PubMed, Cochrane library and Web of Science, using the terms "refugee" and "quality indicator", complemented by a search in reference lists and grey literature. All papers which included Qls for refugees, especially for health care were included. In a first step all existing Qls were screened for their relevance to refugees. In a second step, all health care QIs were extracted. In a final step, these health care QIs were classified into process, structure and outcome indicators.

Results: Of 474 papers, 23 were selected for a full-text review. Of these 23 publications, 6 contained 115 Qls for health and health care for refugees. The main health care topics identified were reproductive health, health care service and health status.

Conclusions: Most indicators were indicators for outcome and structure quality, the smallest group were process indicators. Within the area of refugee health care, most Qls that have been found were Qls regarding reproductive health. QI databases do not yet include indicators specifically related to refugees.
\end{abstract}

Keywords: Quality of health care, Quality indicators, Health care, Refugees, Review

\section{Background}

Health care for refugees and asylum seekers represents a challenge for the health system of the host country for various reasons. Examples are lack of access to health care in the host country and past experience of trauma which may have caused mental health problems. Furthermore, there may be barriers of communication, language and culture [1-3]. As a result of persecution, conflict, generalized violence or human rights violations, 65.3 million people were forcibly displaced worldwide in 2015 [4]. Most refugees were from Syria and over 6.3 million people fled from war [4].

Back in 1995, the UN High Commissioner for Refugees (UNHCR) highlighted the 'urgent need to address the areas of safe motherhood, control of HIV/ AIDS/STD, family planning services, and management of sexual and gender based violence within the overall

\footnotetext{
* Correspondence: Katja.Goetz@uni-luebeck.de

Institute of Family Medicine, University Hospital Schleswig-Holstein, Campus Luebeck, Ratzeburger Allee 160, 23538 Luebeck, Germany
}

primary health care services' [5]. However, the assurance of a good quality of health care for refugees and asylum seekers will be more and more important for the health system in the host countries.

A core dimension of health system performance is health care quality [6]. Quality of care can be defined as 'whether individuals can access the health structures and processes of care which they need and whether the care received is effective' [7]. Furthermore, quality of care should be divided into three dimensions: structure, process and outcome of care, which could result in measureable quality indicators (QI) [8]. QIs are important for the assessment of health care and are essential measurement tools for documentation and improvement of quality of care [9]. Measurable QIs for health care for refugees have not been identified until now. It can be assumed that regular QIs are just as valid for refugees as they are for all other patients. However, there are specific refugee situations like health care in refugee camps for which there should be quality assurance too.

(c) The Author(s). 2019 Open Access This article is distributed under the terms of the Creative Commons Attribution 4.0 International License (http://creativecommons.org/licenses/by/4.0/), which permits unrestricted use, distribution, and 
Therefore, the aims of this systematic review were to evaluate and to extract QIs developed for refugees and asylum seekers.

\section{Methods}

\section{Systematic review}

This systematic review was conducted to find existing QIs, concentrating on those relevant for refugee care, as there are some specific requirements in a typical "refugee situation" as in humanitarian crisis situations, refugee camps, reception centres and health care for refugees and asylum seekers in host countries. Different international and national indicator databases were screened in June 2018. These databases were: the Agency for Health care Research and Quality (AHRQ), the UK's Quality and Outcomes Framework (QOF-UK), the Australian Council on Health care Standards (ACHS), the Scottish Clinical Indicators, the Canadian Institute for Health Information (CIHI), the Dutch National Institute for Public Health and the Environment (RIVM), the RAND Health Quality of Care Assessment Tools (QA Tools), and the German Inpatient Quality Indicators (G-IQI). All databases were searched using the keywords "refugee" or "asylum seeker" to identify potential QIs for this target group.

Furthermore, an additional manual search of grey literature with "Google Scholar" was conducted in June 2018. For this search the terms "quality indicator" AND "refugee" OR "asylum seeker" were used. Additionally, we scrutinized reference lists of included studies and relevant reviews identified through the search. Additionally, we conducted a review by searching PubMed, the Cochrane Library and Web of Science, using "quality indicator" and "refugee" as medical subject headings $(\mathrm{MeSH})$-terms and as text words in June 2018. The search strategy for PubMed was: ("Refugees" [Mesh] OR "refugees" [All Fields]) AND ("Quality Indicators, Health Care" [Mesh] OR "indicators" [All Fields]). The Mesh term refugee included following terms: Refugee, Asylum Seekers; Asylum Seeker; Seekers, Asylum.

The search strategy for web of science was: (refugee* OR asyl" seek*) AND (indicator).

Moreover, we cross checked the reference lists of the publications. If publications contained QIs from other indicator sets, we included the original publication of the mentioned indicator set and excluded the secondary source.

This systematic review was independently performed by two reviewers $(\mathrm{KH}, \mathrm{DW})$, who conducted the literature search and review following the PRISMA guidelines [10]. These two independent reviewers screened titles and abstracts initially for potential relevance. If the abstract matched the inclusion criteria, the full article was obtained and reviewed. After selection of potentially relevant articles, full reports were obtained and assessed for inclusion and exclusion criteria. Any disagreement on the eligibility of studies was resolved through discussion to reach consensus or, if required, by involving a third experienced review author.

Overall, the search strategy was defined by the principles of a systematic search and implied free-text keywords and Mesh terms by two reviewers who were well experienced in conducting Systematic Reviews. No medical librarian was consulted.

\section{Inclusion criteria and screening procedure}

Publications were included if the following inclusion criteria were fulfilled:

- QIs were reported

- QIs were developed for the target group 'refugees and asylum seekers'

- Primary source of QI

- Published in English, French or German

Quantitative and qualitative research was considered. There was no restriction of time or place, all studies from 1980 to 2018 were included in the systematic review. We included both clinical indicators and indicators for practice management. According to the key characteristics of an ideal indicator by Mainz [9] the described indicators had to be specific and measurable with the numerator and denominator principles. In a first step for full-text review, all publications were included that described QIs for refugees and asylum seekers and extracted these indicators. In a second step, all publications were excluded that identified QIs for refugees but did not have a reference to health care. The final step was to classify health care indicators based on the dimensions put forward by Donabedian [8]. These dimensions were structure, process and outcome quality. Two authors (KH and $\mathrm{DW}$ ) independently read and extracted the data from each study included. In cases of disagreement or discrepancies, we involved a third review author (JS) to reach consensus.

An overview of the literature identification and selection is presented in the PRISMA flow chart in Fig. 1.

We charted the following data from the included studies: bibliographic details such as author/source, year of publication, title, and included indicators, especially health care indicators.

\section{Results}

In the QI databases, no indicators could be found that specifically related to refugees or were established for this target group. Using the keywords "refugee" and "asylum seekers" did not provide any results. 


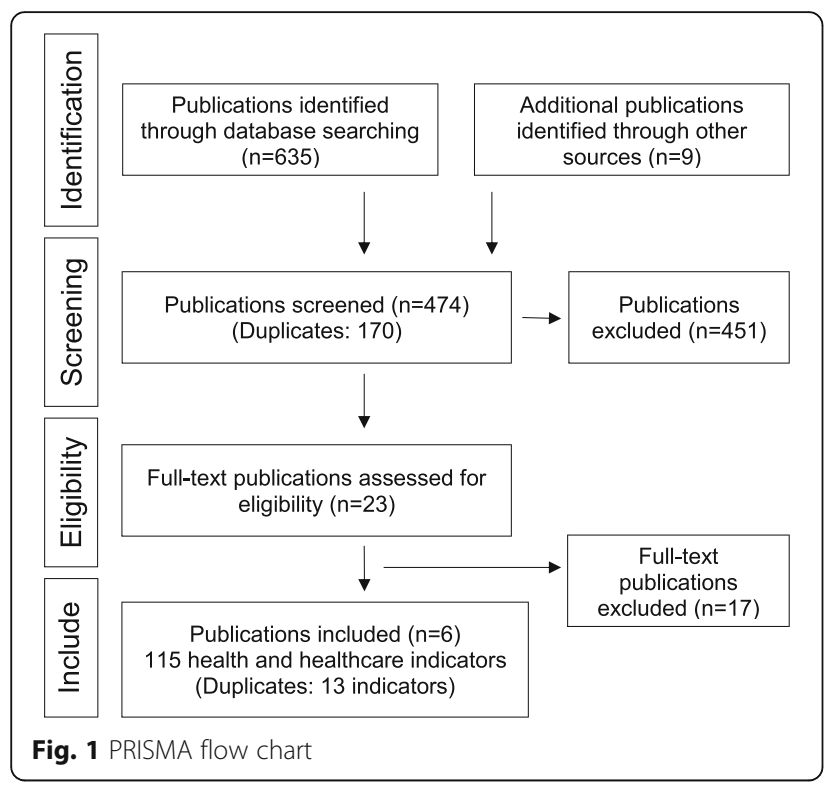

The review of PubMed, Web of Science and grey literature, and publications of reference lists and grey literature revealed 644 papers. The removal of duplicates left 474 papers of which 9 publications were excluded because of publication language, and 23 were eligible for a full-text review [11-33]. Most represented indicators were indicators of integration [11-13, 17], indicators of education $[11-14,17]$ and indicators regarding health care [11-16]. Other studies contained indicators relevant to single topics: indicators of acculturation [19], indicators of cultural participation [20], indicators of refugee placement [21], indicators with a focus on "youth in refugee camps" [22], indicators for assessing infant and child feeding practices [23], and indicators for malnutrition [24].

Publications including indicators from other primary references [25-28] and containing indicators not especially developed for refugees but applicable to this target group [29, 30] were excluded. All 17 publications [17-33] that were not relevant to health care, were excluded. Finally, 115 QIs related to health care for refugees were identified within 6 publications [11-16].

\section{Descriptive analysis}

We found 115 indicators in 6 publications that were applicable to health care for refugees. These included 33 indicators concerning structural quality, 26 indicators concerning process quality and 51 indicators concerning outcome quality. Four indicators related to both process and structural quality and one indicator related to both outcome and process quality. Please see Table 1 for details.

The indicators covered three thematic domains: "reproductive health", "health care service", and "health status". "Reproductive health" was assessed by 58 indicators for family planning, maternal and newborn health and HIV/AIDS. "Health care service" included 46 indicators describing access to health care and health management. "Health status" included 11 indicators such as birth rates, mortality rates, and diseases. All health care indicators were listed and sorted according to

Table 1 Overview of the number of indicators related to health and health care of refugees

\begin{tabular}{|c|c|c|c|c|c|}
\hline Source & Title & Year & Ref. & Topics & $\begin{array}{l}\text { Donabedian framework } \\
\text { (number of indicators) }\end{array}$ \\
\hline Sphere Project & The Sphere Project & 2007 & 15 & $\begin{array}{l}\text { Health care services } \\
\text { Reproductive health } \\
\text { Health status }\end{array}$ & $\begin{array}{l}\text { Process }=15 \\
\text { Structure }=13 \\
\text { Outcome }=7 \\
\text { Structure and Process = } 3\end{array}$ \\
\hline $\begin{array}{l}\text { United Nations High Commissioner } \\
\text { for Refugees }\end{array}$ & $\begin{array}{l}\text { Inter-agency Field Manual on } \\
\text { Reproductive Health in } \\
\text { Humanitarian Settings }\end{array}$ & 2010 & 16 & Reproductive health & $\begin{array}{l}\text { Process }=7 \\
\text { Structure }=8 \\
\text { Outcome }=31\end{array}$ \\
\hline $\begin{array}{l}\text { United Nations High Commissioner } \\
\text { for Refugees }\end{array}$ & $\begin{array}{l}\text { Practical Guide to the Systematic Use of } \\
\text { STANDARDS \& INDICATORS in UNHCR } \\
\text { Operations }\end{array}$ & 2006 & 14 & Health status & $\begin{array}{l}\text { Process }=2 \\
\text { Structure }=8 \\
\text { Outcome }=8\end{array}$ \\
\hline $\begin{array}{l}\text { Home Office Development and Practice } \\
\text { Reports: Indicators of Integration }\end{array}$ & Indicators of Integration & 2004 & 12 & Health care services & $\begin{array}{l}\text { Process }=2 \\
\text { Structure }=2 \\
\text { Outcome }=3 \\
\text { Outcome and Process }=1 \\
\text { Structure and Process }=1\end{array}$ \\
\hline OECD & Indicators of Immigrant Integration & 2015 & 11 & Health status & Outcome $=2$ \\
\hline UNHCR & $\begin{array}{l}\text { Refugee Integration and The Use } \\
\text { Of Indicators: Evidence From } \\
\text { Central Europe }\end{array}$ & 2013 & 13 & Health care services & Structure $=2$ \\
\hline
\end{tabular}


these three topic domains. If indicators could be assigned to several topics, they were only listed in the predominant category.

\section{Reproductive health}

The reproductive health indicators found in the literature covered various thematic domains. There were preventive indicators such as "number of condoms distributed per person per month" [14] and "condom use" [11], indicators regarding pregnancy or maternal and child health and some indicators regarding HIV/ AIDS. The topic of reproductive health was the largest group of indicators identified within our review. Additionally, UNHCR focused on this domain in their publications $[14,16]$, and 8 indicators from the Sphere Project [15] were relevant to this topic.

Within this topic, there were 11 indicators for structural quality, 14 indicators regarding process quality and 32 outcome indicators. All indicators regarding reproductive health for refugees are listed in Table 2.

\section{Health care services}

Within this thematic domain there were 46 indicators that focused on various topics such as access to health care for refugees, training of staff and processes necessary for safe individual and public health. Most indicators in this group were from the Sphere Project (26 indicators), which defines minimum standards for disaster-affected populations [17]. Within this topic there were 22 indicators for structural quality, 12 indicators regarding process quality and 8 outcome indicators.

All indicators regarding health care services for refugees are listed in Table 3.

\section{Health status}

Within this group, there were 11 outcome indicators. They covered topics including "self-reported health status" [11] and incidence, mortality and birth rates [12, 14, 15]. All indicators regarding the health status of refugees are listed in Table 4.

Most of the indicators were outcome indicators $(n=51 ; 44.35 \%)$, structural quality was represented with 33 indicators (28.7\%) and the smallest group were indicators of process quality $(n=26 ; 22.61 \%)$. Four indicators (3.48\%) addressed both process and structural quality and one indicator addressed both outcome and process quality.

\section{Discussion}

This systematic review shows evidence concerning QIs for health care of refugees and asylum seekers. Different databases were used and 115 indicators that related to health care of refugees were identified. These different indicators could be sorted into three topics, "reproductive health", "health services" and "health status" including a categorisation into the Donabedian quality dimensions: process, structure or outcome of care. Most indicators were outcome indicators and focused on mortality and morbidity; process indicators represented the smallest group of indicators. Most of the indicators address items concerning reproductive health and maternal and child health. There are many indicators focusing on these topics due to a marked need for addressing highly prevalent conditions that should be addressed in future research. Access to high-quality reproductive health services including appropriate emergency obstetrics can drastically reduce the number of women who die during or after childbirth, ensuring that mothers and their children enjoy a healthy life. UNHCR applied the principle that reproductive health care should be offered to all refugee women [16]. Quality reproductive health services require that organizations, programs and providers use appropriate technology, have trained staff, and ensure accessible services and respectful care.

Although WHO and UNHCR have highlighted the importance of reproductive health in refugee situations, a systematic review about refugee health status shows no study regarding physical health of women during pregnancy and childbirth. The authors identify a priority need for research in this context [34].

The second largest group of indicators observed in this review are indicators concerning the topic of health care services, such as access to health care. Access to health care is a critical determinant of survival in refugee situations such as disasters. The right to health can be assured only if the health care providers responsible for the health system are well trained and comply with professional standards [15]. The organisation of health care for refugees and access to health care present a challenge for the host countries. Refugees often have no regular access to health care and they struggle with restricted access to health care in their host countries [35]. There should be standards for refugee health care access similar to the Sphere-Standards for disaster-affected populations [15]. Moreover, the provision of health care services for refugees and asylum seekers presents also a challenge for the health care providers. A systematic review shows that health care providers struggle not only with the diverse cultural beliefs and language differences but also with limited institutional capacities which additionally restrict the access to health care [36].

The third topic, indicators for health status, only contains outcome indicators such as morbidity and mortality which are connected to the indicators of reproductive health and health services. The quality of life in the country of origin, the migration process and the conditions in the host country could influence the health 
Table 2 Indicators of the topic reproductive health

\begin{tabular}{|c|c|c|}
\hline Source & Donabedian framework & Indicator \\
\hline Sphere (2007) [15] & Structure & $\begin{array}{l}\text { There are at least four health facilities with BEmOC and newborn } \\
\text { care/500,000 population. }\end{array}$ \\
\hline Sphere (2007) [15] & Structure & $\begin{array}{l}\text { There is at least one health facility with CEmOC and newborn } \\
\text { care } / 500,000 \text { population. }\end{array}$ \\
\hline UNHCR (2010) [16] & Structure & Coverage of Supplies for Standard Precautions \\
\hline UNHCR (2010) [16] & Structure & Coverage of HIV Rapid Tests for Safe Blood Transfusion \\
\hline UNHCR (2010) [16] & Structure & Coverage of Clean Delivery Kits \\
\hline UNHCR (2010) [16] & Structure & Availability of clinical management of rape survivors \\
\hline UNHCR (2010) [16] & Structure & Contraceptive supply \\
\hline UNHCR (2010) [16] & Structure & EmOC services availability \\
\hline UNHCR (2010) [16] & Structure & STI/RTI management skills of service providers \\
\hline UNHCR (2010) [16] & Structure & STI/RTI case management \\
\hline UNHCR (2006) [14] & Structure & Number of condoms distributed per person per month \\
\hline UNHCR (2010) [16] & Process & Timing of PEP provision \\
\hline UNHCR (2010) [16] & Process & Timing of emergency contraception (EC) provision \\
\hline UNHCR (2010) [16] & Process & Timing of STI prophylaxis \\
\hline Sphere (2007) [15] & Process & $\begin{array}{l}\text { All pregnant women in their third trimester have received clean } \\
\text { delivery kits. }\end{array}$ \\
\hline Sphere (2007) [15] & Process & $\begin{array}{l}\text { People most at risk of exposure to HIV are targeted with an HIV } \\
\text { prevention program. }\end{array}$ \\
\hline Sphere (2007) [15] & Process & $\begin{array}{l}\text { Pregnant women known to be HIV positive have received ARV } \\
\text { drugs for PMTCT. }\end{array}$ \\
\hline Sphere (2007) [15] & Process & $\begin{array}{l}100 \% \text { of transfused blood is screened for transfusion-transmissible } \\
\text { infections including HIV. }\end{array}$ \\
\hline Sphere (2007) [15] & Process & $\begin{array}{l}\text { Individuals potentially exposed to HIV (occupational exposure in } \\
\text { health care settings and non-occupational exposure) have } \\
\text { received PEP within } 72 \mathrm{~h} \text { of an incident. }\end{array}$ \\
\hline UNHCR (2010) [16] & Process & Investigation of maternal deaths \\
\hline UNHCR (2010) [16] & Process & EmOC services utilization \\
\hline UNHCR (2010) [16] & Process & Abortion services performed with appropriate technology \\
\hline UNHCR (2010) [16] & Process & Awareness of legal indications for termination of pregnancy \\
\hline UNHCR (2006) [14] & Process & Have stocks of condoms run out for more than a week? \\
\hline UNHCR (2006) [14] & Process & $\begin{array}{l}\text { Are there any specific interventions directed at refugees/ } \\
\text { foreseen in the HIV/AIDS national strategic plan? }\end{array}$ \\
\hline Home Office (2004) [12] & Outcome/Process & $\begin{array}{l}\text { Immunization, antenatal care and cervical and breast screening } \\
\text { (coverage compared with general population) }\end{array}$ \\
\hline Sphere (2007) [15] & Outcome & $\begin{array}{l}\text { The proportion of deliveries by caesarean section is not less } \\
\text { than } 5 \% \text { or more than } 15 \%\end{array}$ \\
\hline UNHCR (2010) [16] & Outcome & Number of Reported Rape Cases \\
\hline UNHCR (2010) [16] & Outcome & Condom Distribution Rate \\
\hline UNHCR (2010) [16] & Outcome & Incidence of STD in young people \\
\hline UNHCR (2010) [16] & Outcome & Proportion of STI among those under 18 years \\
\hline UNHCR (2010) [16] & Outcome & Proportion of births among those under 18 years \\
\hline UNHCR (2010) [16] & Outcome & Condom use among young people \\
\hline UNHCR (2010) [16] & Outcome & Contraceptive prevalence (CP) \\
\hline UNHCR (2010) [16] & Outcome & Community knowledge concerning family planning (FP) \\
\hline UNHCR (2010) [16] & Outcome & Coverage of FP counseling \\
\hline UNHCR (2010) [16] & Outcome & Neonatal mortality rate \\
\hline
\end{tabular}


Table 2 Indicators of the topic reproductive health (Continued)

\begin{tabular}{|c|c|c|}
\hline Source & Donabedian framework & Indicator \\
\hline UNHCR (2010) [16] & Outcome & Proportion of low birth weight \\
\hline UNHCR (2010) [16] & Outcome & Stillbirth rate \\
\hline UNHCR (2010) [16] & Outcome & Complete antenatal care \\
\hline UNHCR (2010) [16] & Outcome & Coverage of syphilis screening \\
\hline UNHCR (2010) [16] & Outcome & Tetanus vaccination coverage \\
\hline UNHCR (2010) [16] & Outcome & EmOC needs met \\
\hline UNHCR (2010) [16] & Outcome & Percentage of births assisted by a skilled attendant \\
\hline UNHCR (2010) [16] & Outcome & Coverage of postpartum care \\
\hline UNHCR (2010) [16] & Outcome & Percentage of deliveries by Caesarean section, by administrative unit \\
\hline UNHCR (2010) [16] & Outcome & Direct obstetric case fatality rate \\
\hline UNHCR (2010) [16] & Outcome & Coverage of post-abortion contraception \\
\hline UNHCR (2010) [16] & Outcome & Coverage of induced abortion \\
\hline UNHCR (2010) [16] & Outcome & Number of cases of sexual violence reported to health services \\
\hline UNHCR (2010) [16] & Outcome & Incidence of genital ulcer disease \\
\hline UNHCR (2010) [16] & Outcome & Incidence of male urethral discharge \\
\hline UNHCR (2010) [16] & Outcome & Quality of blood donation screening \\
\hline UNHCR (2010) [16] & Outcome & VCT post-test counselling and result \\
\hline UNHCR (2010) [16] & Outcome & PMTCT coverage \\
\hline UNHCR (2010) [16] & Outcome & PMTCT post-test counselling and result \\
\hline UNHCR (2010) [16] & Outcome & Coverage of ARV in PMTCT programs \\
\hline UNHCR (2010) [16] & Outcome & Condom use \\
\hline
\end{tabular}

BEmOC Basic Emergency Obstetric Care, CEmOC Comprehensive Emergency Obstetric Care Services, EmOC Emergency Obstetric Care Services, STI/RTI sexually transmitted infections/ reproductive tract infections, PEP postexposure prophylaxis to prevent HIV transmission, ARV antiretrovirals, PMTCT prevention of motherto-child transmission, STD sexually transmitted diseases, VCT voluntary counselling and testing

outcomes of refugees. Refugees may be more vulnerable to certain diseases or mental disorders than people without such experiences. The migration experience itself could create stress which could influence the health outcomes of migrants in different ways depending on the socio-economic and health conditions in the country of origin [11].

As complement to our systematic review a recently published evidence report concludes that there is a lack of common strategies for health care management of refugees and asylum seekers [3]. Owing to different legal frameworks in the host countries, no general conclusion about the accessibility and quality of health care delivery can be adopted [3]. It can be assumed that generic QIs could overcome this barrier and help to optimize and improve the health care of refugees and asylum seekers. A further review shows that different guidelines for migrant health care are available that range from disease specific to generic guidelines for health care delivery which could have an impact on quality of health care [37]. A systematic use of such guidelines, especially of the developed QIs, in the health care process of this population group is essential to ensure a high-quality of health care.
The main strength of our systematic review was the presentation of numerous and diverse areas in which QIs for refugee care were developed. The search strategy was defined by the principles of a systematic search and implied free-text keywords and Mesh terms by two reviewers who were well experienced in conducting Systematic Reviews. No medical librarian was consulted.

However, we only included publications written in English, French or German. Moreover, because of the clear defined search strategy it could be that some institutes on provincial level in different countries like the Institute of Clinical Evaluative Sciences in Ontario, Canada showed no QI for health care of refugees. Therefore, there might be a selection bias in our findings.

\section{Conclusions}

It can be concluded that most indicators stress outcome. It can be assumed that an effective process within health care services supports high-quality of health care and should be the focus of further studies. QIs are an important measurement tool for the documentation and improvement of health care. Further research needs to address explicitly measurable QIs to learn more 
Table $\mathbf{3}$ Indicators for the topic health care services

\begin{tabular}{|c|c|c|}
\hline Source & Donabedian framework & Indicator \\
\hline Home Office (2004) [12] & Structure/Process & $\begin{array}{l}\text { Strategies identifiable at health authority/board level for addressing } \\
\text { priority health needs among refugee populations }\end{array}$ \\
\hline Sphere (2007) [15] & Structure/Process & $\begin{array}{l}\text { No health facility is out of stock of selected essential medicines and tracer } \\
\text { products for more than one week }\end{array}$ \\
\hline Sphere (2007) [15] & Structure/Process & $\begin{array}{l}\text { A written outbreak investigation and response plan is available or } \\
\text { developed at the beginning of a disaster response. }\end{array}$ \\
\hline Sphere (2007) [15] & Structure/Process & $\begin{array}{l}\text { All primary health care facilities have clear standard operating procedures } \\
\text { for referrals of patients with NCDs to secondary and tertiary care facilities. }\end{array}$ \\
\hline Home Office (2004) [12] & Structure & $\begin{array}{l}\text { Proportion of refugees registered with a General Practitioner (compared } \\
\text { with general population) }\end{array}$ \\
\hline Home Office (2004) [12] & Structure & The number of refugee doctors and nurses joining professional registers \\
\hline \multirow[t]{5}{*}{ Sphere (2007) [15] } & \multirow[t]{5}{*}{ Structure } & $\begin{array}{l}\text { There are an adequate number of health facilities to meet the essential } \\
\text { health needs of all the disaster-affected population: }\end{array}$ \\
\hline & & $\begin{array}{l}\text { - one basic health unit/10,000 population members (basic health units } \\
\text { are primary health care facilities where general health services are } \\
\text { offered), }\end{array}$ \\
\hline & & - one health center/50,000 people, \\
\hline & & - one district or rural hospital/250,000 people, \\
\hline & & - > 10 inpatient and maternity beds/10,000 people \\
\hline
\end{tabular}

Sphere (2007) [15] Structure

Sphere (2007) [15] Structure

Sphere (2007) [15]

Structure

Sphere (2007) [15] _ Structure

Sphere (2007) [15] Structure

Sphere (2007) [15]

Structure

Sphere (2007) [15]

Structure

Sphere (2007) [15] Structure

Sphere (2007) [15] Structure

Sphere (2007) [15]

Structure

UNHCR (2006) [14]

UNHCR (2006) [14]

UNHCR (2006) [14]

UNHCR (2006) [14]
Structure

Structure

Structure

Structure

Utilization rates at health facilities are 2-4 new consultations/person/year among the disaster-affected population and $>1$ new consultations/person/year among rural and dispersed populations

There are:

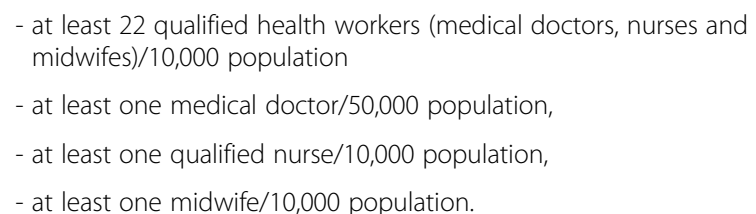

There is at least one Community Health Worker (CHW)/1000 population, one supervisor/10 home visitors and one senior supervisor.

Clinicians are not required to consult more than 50 patients a day consistently. If this threshold is regularly exceeded, additional clinical staff are recruited.

Primary health care services are provided to the disaster-affected population free of charge at all government and non-governmental organization facilities for the duration of the disaster response.

All health facilities have trained staff, sufficient supplies and equipment for clinical management of rape survivor services based on national or WHO protocols.

All primary health care facilities have antimicrobials to provide syndromic management to patients presenting with symptoms of an STI.

All health facilities have trained staff and systems for the management of multiple casualties.

All health facilities have trained staff and systems for the management of mental health problems.

All primary health care facilities have adequate medication for continuation of treatment of individuals with NCDs who were receiving treatment before the emergency.

Do returnees have access to emergency and primary health care services without discrimination?

Will there be a possibility for returnee to continue ART in returnee area? Number of persons per primary health care facility Annual no. of consultations at primary health care facilities per person 
Table 3 Indicators for the topic health care services (Continued)

\begin{tabular}{|c|c|c|}
\hline Source & Donabedian framework & Indicator \\
\hline UNHCR (2006) [14] & Structure & Percentage of live births attended by skilled personnel (excl. TBAs) \\
\hline UNHCR (2006) [14] & Structure & $\begin{array}{l}\text { Do asylum-seekers/refugees have access to antiretroviral therapy from any } \\
\text { source, if available in hosting community? }\end{array}$ \\
\hline UNHCR (2006) [14] & Structure & Do asylum-seekers/refugees have access to primary health care services? \\
\hline UNHCR (2013) [13] & Structure & Health Insurance Requirement \\
\hline UNHCR (2013) [13] & Structure & Access to health care \\
\hline Home Office (2004) [12] & Process & $\begin{array}{l}\text { Refugee involvement in Patient Advisory \& Liaison Services and similar } \\
\text { initiatives }\end{array}$ \\
\hline Home Office (2004) [12] & Process & $\begin{array}{l}\text { Patient information available in culturally appropriate form regarding } \\
\text { service entitlements, provision and relevant health risks. }\end{array}$ \\
\hline Sphere (2007) [15] & Process & $\begin{array}{l}\text { All health facilities and agencies regularly provide a HIS report within } 48 \mathrm{~h} \\
\text { of the end of the reporting period to the lead agency. }\end{array}$ \\
\hline Sphere (2007) [15] & Process & $\begin{array}{l}\text { All health facilities and agencies report cases of epidemic-prone diseases } \\
\text { within } 24 \mathrm{~h} \text { of onset of illness. }\end{array}$ \\
\hline Sphere (2007) [15] & Process & $\begin{array}{l}\text { The lead agency produces a regular overall health information report, } \\
\text { including analysis and interpretation of epidemiological data, as well as a } \\
\text { report on the coverage and utilization of the health services. }\end{array}$ \\
\hline Sphere (2007) [15] & Process & $\begin{array}{l}\text { The lead agency has developed a health sector response strategy } \\
\text { document to prioritize interventions and define the role of the lead and } \\
\text { partner agencies at the onset of an emergency response. }\end{array}$ \\
\hline Sphere (2007) [15] & Process & $\begin{array}{l}\text { Standardized case management protocols for the diagnosis and treatment } \\
\text { of common infectious diseases are readily available and consistently used. }\end{array}$ \\
\hline Sphere (2007) [15] & Process & $\begin{array}{l}\text { Health agencies report suspected outbreaks to the next appropriate level } \\
\text { within the health system within } 24 \mathrm{~h} \text { of detection. }\end{array}$ \\
\hline Sphere (2007) [15] & Process & $\begin{array}{l}\text { The lead health agency initiates investigation of reported cases of } \\
\text { epidemic prone diseases within } 48 \mathrm{~h} \text { of notification. }\end{array}$ \\
\hline Sphere (2007) [15] & Process & $\begin{array}{l}\text { All children under } 5 \text { years old presenting with malaria have received } \\
\text { effective antimalarial treatment within } 24 \mathrm{~h} \text { of onset of their symptoms. }\end{array}$ \\
\hline Sphere (2007) [15] & Process & $\begin{array}{l}\text { All children under } 5 \text { years of age presenting with diarrhea have received } \\
\text { both oral rehydration salts (ORS) and zinc supplementation. }\end{array}$ \\
\hline Sphere (2007) [15] & Process & $\begin{array}{l}\text { All children under } 5 \text { years of age presenting with pneumonia have } \\
\text { received appropriate antibiotics. }\end{array}$ \\
\hline Home Office (2004) [12] & Outcome & $\begin{array}{l}\text { Utilization rates of specialized services (e.g., antenatal care, mental health } \\
\text { services, chiropody services, NHD Direct, etc.) by refugees (compared with } \\
\text { general population) }\end{array}$ \\
\hline Home Office (2004) [12] & Outcome & Refugees reported satisfaction with service provision. \\
\hline OECD (2015) [11] & Outcome & Health care \\
\hline \multirow[t]{3}{*}{ Sphere (2007) [15] } & \multirow[t]{3}{*}{ Outcome } & Upon completion of measles vaccination campaign: \\
\hline & & $\begin{array}{l}\text { - at least 95\% of children aged } 6 \text { months to } 15 \text { years have received } \\
\text { measles vaccination; }\end{array}$ \\
\hline & & $\begin{array}{l}\text { - at least 95\% of children aged 6-59 months have received an } \\
\text { appropriate dose of Vitamin A. }\end{array}$ \\
\hline Sphere (2007) [15] & Outcome & $\begin{array}{l}\text { Once routine EPI services have been re-established, at least 90\% of chil- } \\
\text { dren aged } 12 \text { months have had three doses of DPT (diphtheria, pertussis } \\
\text { and tetanus), which is the proxy indicator for fully immunized children. }\end{array}$ \\
\hline UNHCR (2006) [14] & Outcome & Measles vaccination coverage rate \\
\hline UNHCR (2006) [14] & Outcome & $\begin{array}{l}\text { Percentage of female members in asylum seeker/refugee representative } \\
\text { bodies }\end{array}$ \\
\hline UNHCR (2006) [14] & Outcome & Percentage of needs met for sanitary materials \\
\hline
\end{tabular}


Table 4 Indicators for the topic health status

\begin{tabular}{|c|c|c|}
\hline Source & Donabedian framework & Indicator \\
\hline Home Office (2004) [12] & Outcome & Morbidity and mortality rates compared with the general population \\
\hline OECD (2015) [11] & Outcome & Self-reported health status \\
\hline Sphere (2007) [15] & Outcome & $\begin{array}{l}\text { The crude mortality rate (CMR) is maintained at, or reduced to, less than } \\
\text { double the baseline rate documented for the population prior to the } \\
\text { disaster. }\end{array}$ \\
\hline Sphere (2007) [15] & Outcome & $\begin{array}{l}\text { The under- } 5 \text { mortality rate (U5MR) is maintained at, or reduced to, less } \\
\text { than double the baseline rate documented for the population prior to } \\
\text { the disaster. }\end{array}$ \\
\hline Sphere (2007) [15] & Outcome & $\begin{array}{l}\text { Incidence of major communicable diseases relevant to the context are } \\
\text { stable (not increasing). }\end{array}$ \\
\hline \multirow[t]{7}{*}{ Sphere (2007) [15] } & Outcome & Case fatality rates (CFRs) are maintained below acceptable levels: \\
\hline & & - cholera - $1 \%$ or lower \\
\hline & & - Shigella dysentery - $1 \%$ or lower \\
\hline & & - typhoid - 1\% or lower \\
\hline & & - meningococcal meningitis - varies, 5-15\% \\
\hline & & - malaria - varies, aim for $<5 \%$ in severely ill malaria patients \\
\hline & & $\begin{array}{l}\text { - measles - varies, 2-21\% reported in conflict-affected settings, aim } \\
\text { for }<5 \%\end{array}$ \\
\hline UNHCR (2006) [14] & Outcome & Infant Mortality Rate (< 1 year) (returnees and non-returnees) \\
\hline UNHCR (2006) [14] & Outcome & Child Mortality Rate (< 5 years) (returnees and non-returnees) \\
\hline UNHCR (2006) [14] & Outcome & Crude Mortality Rate (returnees and non-returnees) \\
\hline UNHCR (2006) [14] & Outcome & $\begin{array}{l}\text { Percentage of newborn children with low birth weight }(<2500 \mathrm{~g} \text {.) } \\
\text { (weighed within } 72 \mathrm{~h} \text { ) }\end{array}$ \\
\hline UNHCR (2006) [14] & Outcome & Crude Birth Rate (annual) \\
\hline
\end{tabular}

about health care for refugees and asylum seekers. Moreover, it can be assumed that a smaller number of indicators can be better implemented in health care of refugees. Therefore, the next step would be the reduction and prioritisation of these 115 indicators e.g. based on the RAND/UCLA Method [38].

\begin{abstract}
Abbreviations
ACHS: Australian Council on Health care Standards; AHRQ: Agency for Health care Research and Quality; ART: Antiretroviral therapy; ARV: Antiretrovirals; BEmOC: Basic Emergency Obstetric Care; CEmOC: Comprehensive emergency obstetric care services; $\mathrm{ClHI}$ : Canadian Institute for Health Information; e.g.: Exempli gratia/ for example; EmOC: Emergency obstetric care services; EPI: Expanded program on immunization; G-IQI: German inpatient quality indicators; NCD: Noncommunicable diseases;

OECD: Organisation for economic co-operation and development; PEP: Postexposure prophylaxis to prevent HIV transmission; PMTCT: Prevention of mother-to child transmission; QA Tools: RAND Health Quality of Care Assessment Tools; QI: Quality indicators; QOF-UK: UK's Quality and Outcomes Framework; RIVM: Dutch National Institute for Public Health and the Environment; RTI: Reproductive tract infections; STD: Sexually transmitted diseases; STI: Sexually transmitted infection(s); TBA: Traditional birth attendant(s); UNHCR: United Nations High Commissioner for Refugees; VCT: Voluntary counselling and testing; WHO: World Health Organization
\end{abstract}

\section{Acknowledgements}

We gratefully thank Native Speaker Andrea Strathausen for reviewing this manuscript.

\section{Authors' contributions}

$\mathrm{KH}$ participated in the conception and design of the review, conducted the literature search, screened the documents using inclusion and exclusion criteria, extracted data from retained publications, synthesized the findings and drafted the manuscript. DW screened the documents using inclusion and exclusion criteria and synthesized the findings. In cases of disagreement or discrepancies, JS became involved to reach consensus. KG participated in the conception and design of the review and drafted the manuscript. All authors have reviewed the submitted manuscript and approve the manuscript for submission.

\section{Funding}

This review is part of a study about healthcare of refugees, which was funded by the Damp Stiftung, No: 2015-22. The funding body did not influence the design of the study and was not involved in collection, analysis, and interpretation of data and in writing the manuscript.

\section{Availability of data and materials}

The datasets used and analyzed during the current study are available from the corresponding author upon reasonable request.

Ethics approval and consent to participate

Not applicable.

\section{Consent for publication}

Not applicable.

\section{Competing interests}

The authors declare that they have no competing interests. 
Received: 17 September 2018 Accepted: 6 June 2019

Published online: 13 June 2019

\section{References}

1. Eckstein B. Primary care for refugees. Am Fam Physician. 2011;83:429-36.

2. McMurray J, Breward K, Breward M, Alder R, Arya N. Integrated primary care improves access to health care for newly arrived refugees in Canada. J Immigr Minor Health. 2014;16:576-85.

3. Bradby $H$, Humphris $R$, Newall D, Phillimore J. Public health aspects of migrant health: a review of the evidence on health status for refugees and asylum seekers in the European region. Copenhagen: WHO; 2015. http:// www.euro.who.int/_data/assets/pdf_file/0004/289246/WHO-HEN-ReportA5-2-Refugees_FINAL.pdf. Accessed 23 July 2018

4. United Nations high commissioner for refugees (UNHCR): global trends. Forced displacement in 2015. http://www.unhcr.org/statistics. Accessed 23 July 2018.

5. UNHCR. Refugee health, 1995. http://www.unhcr.org/excom/scaf/3ae68bf424/ refugee-health.html. Accessed 23 July 2018

6. Smith PC, Mossialos E, Papanicolas I, Leatherman S. Performance measurement for health system improvement: experiences, challenges and prospects: Cambridge University Press; 2009. http://www.euro.who.int/en/about-us/ partners/observatory/publications/studies/performance-measurement-forhealth-system-improvement-experiences,-challenges-and-prospects-2009. Accessed 23 July 2018

7. Campbell SM, Roland MO, Buetow SA. Defining quality of care. Soc Sci Med. 2000:51:1611-25.

8. Donabedian A. The quality of care. How can it be assessed? JAMA. 1988; 260:1743-8.

9. Mainz J. Defining and classifying clinical indicators for quality improvement. Int J Qual Health Care. 2003:15:523-30.

10. Moher D, Liberati A, Tetzlaff J, Altman DG, The PRISMA group 2009. Preferred reporting items for systematic reviews and meta-analyses: The PRISMA Statement Group. PloS Med. 2009;6:e1000097.

11. OECD/European Union. Indicators of immigrant integration 2015. Paris: OECD Publishing; 2015. https://doi.org/10.1787/9789264234024-en. Accessed 23 July 2018

12. Ager A, Strang A. Indicators of integration: final report. London: Home Office development and practice report 28, 2004.

13. UNHCR. Refugee integration and the use of indicators: evidence from central Europe: http://www.refworld.org/docid/532164584.html. Accessed 23 July 2018.

14. UNHCR. Practical guide to the systematic use of standards \& indicators in UNHCR operations. Geneva, 2006.

15. Sphere project. Sphere handbook. Geneva, 2007.

16. UNHCR. Inter-agency field manual on reproductive health in humanitarian settings: http://www.unhcr.org/protection/health/4c187e5b6/inter-agencyfield-manual-reproductive-health-humanitarian-settings-2010.html. Accessed 23 July 2018.

17. Huddleston T, Niessen J, Dag Tjaden J. Using EU indicators of immigrant integration. Final report for directorate-general for home affairs. European Commission 2013; doi:https://doi.org/10.2837/34091

18. Inter-Agency Network for Education in Emergencies (INEE). Minimum standards for education in emergencies, chronic crises and early reconstruction: https://www.unicef.org/violencestudy/pdf/min_standards_ education_emergencies.pdf. Accessed 23 July 2018.

19. Flynn PM, Foster EM, Brost BC. Indicators of acculturation related to Somali refugee women's birth outcomes in Minnesota. J Immigr Minor Health. 2011:13:224-31

20. Khawaja M, Barazi R, Linos N. Maternal cultural participation and child health status in a middle eastern context: evidence from an urban health study. Child Care Health Dev. 2007:33:117-25.

21. U.S. Department of health and human services. Key indicators for refugee placement in FY, 2014. https://www.acf.hhs.gov/sites/default/files/orr/fy_ 2014_placement_briefing.pdf. Accessed 23 July 2018.

22. Makhoul J, Nakkash R. Understanding youth: using qualitative methods to verify quantitative community indicators. Health Promot Pract. 2009;10: 128-35.

23. Seal A, Mcgrath M, Seal A, Taylor A. Infant feeding indicators for use in emergencies: an analysis of current recommendations and practice. Public Health Nutr. 2002;5:365-72.
24. UNHCR. Operational guidance on the use of special nutritional products to reduce micronutrient deficiencies and malnutrition in refugee populations. Geneva; 2011.

25. Qayum M, Anwar S, Raza UA, Qayum E, Qayum N, Qayum F. Assessment of health services on relevant primary health care principles in internally displaced people of Pakistan based on sphere standards and indicators. J Coll Physicians Surg Pak. 2011;21:315-6.

26. Cronin AA, Shrestha D, Cornier N, Abdalla F, Ezard N, Aramburu C. A review of water and sanitation provision in refugee camps in association with selected health and nutrition indicators - the need for integrated service provision. J Water Health. 2008:6:1-13.

27. Whitmill J, Blanton C, Doraiswamy S, Cornier N, Schilperood M, Spiegel P, Tomczyk B. Retrospective analysis of reproductive health indicators in the United Nations high commissioner for refugees post-emergency camps 2007-2013. Confl Health. 2016:10:3.

28. Hynes M, Sheik M, Wilson HG, Spiegel P. Reproductive health indicators and outcomes among refugee and internally displaced persons in postemergency phase camps. JAMA. 2002;288:595-603.

29. Tatah L, Delbiso TD, Rodriguez-Llanes JM, Gil Cuesta J, Guha-Sapir D. Impact of refugees on local health systems: a difference-in-differences analysis in Cameroon. PLoS One. 2016;11:e0168820.

30. Spiegel PB, Le PV. HIV behavioural surveillance surveys in conflict and postconflict situations: a call for improvement. Glob Public Health. 2006;1:147-56.

31. Gagnon AJ, Van Hulst A, Merry L, George A, Saucier JF, Stanger E, Wahoush O, Stewart DE. Cesarean section rate differences by migration indicators. Arch Gynecol Obstet. 2013:287:633-9.

32. Meynard JB, Nau A, Halbert E, Todesco A. Health indicators in children from Meulaboh, Indonesia, following the tsunami of December 26, 2004. Mil Med. 2008;173:900-5.

33. Van Hanegem N, Miltenburg AS, Zwart JJ, Bloemenkamp KW, Van Roosmalen J. Severe acute maternal morbidity in asylum seekers: a two-year nationwide cohort study in the Netherlands. Acta Obstet Gynecol Scand. 2011:90:1010-6.

34. Bozorgmehr K, Mohsenpour A, Saure D, Stock C, Loerbroks A, Joos S, Schneider C. Systematic review and evidence mapping of empirical studies on health status and medical care among refugees and asylum seekers in Germany (1990-2014). Bundesgesundheitsblatt Gesundheitsforschung Gesundheitsschutz. 2016;59:599-620 (in German).

35. Bozorgmehr K, Razum O. Effect of restricting access to health care on health expenditures among asylum-seekers and refugees: a quasi-experimental study in Germany, 1994-2013. PLoS One. 2015;10:e0131483.

36. Suphanchaimat R, Kantamaturapoj K, Putthasri W, Prakongsai P. Challenges in the provision of health care services for migrants: a systematic review through providers' lens. BMC Health Serv Res. 2015;15:390.

37. Agbata EN, Padilla PF, Agbata IN, Armas LH, Solà I, Pottie K, Alonso-Coello P. Migrant health care guidelines: a systematic quality assessment. J Immigr Minor Health. 2018. https://doi.org/10.1007/s10903-018-0759-9.

38. Fitch K, Bernstein SJ, Aguilar MA, Burnand B, LaCalle JR, Lázaro P, van het Loo M, McDonnell J, Vader JP, Kahan JP. The RAND/UCLA appropriateness method user's manual. 2001. https://www.rand.org/pubs/monograph reports/MR1269.html. Accessed 01 April 2019.
Ready to submit your research? Choose BMC and benefit from:
- fast, convenient online submission
- thorough peer review by experienced researchers in your field
- rapid publication on acceptance
- support for research data, including large and complex data types
- gold Open Access which fosters wider collaboration and increased citations
- maximum visibility for your research: over $100 \mathrm{M}$ website views per year
At BMC, research is always in progress.
Learn more biomedcentral.com/submission 